Limnol. Rev. (2021) 21, 1: 63-71

DOI 10.2478/limre-2021-0006

\title{
Sciendo
}

\section{River minimum flow changes under dammed reservoir conditions}

\author{
Edmund Tomaszewski
}

University of Łódź, Faculty of Geographical Sciences, Institute of Climatology and Hydrology, Department of Hydrology and Water Management, Narutowicza 88, 90-139 Łódź, Poland, e-mail: edmund.tomaszewski@geo.uni.lodz.pl

\begin{abstract}
The main aim of this study was to assess what range of downstream low flow changes is caused by dam construction directly. An investigation was based on the assumption that the difference in change ratio of flow between gauging cross-sections located downstream and upstream position of dammed reservoir identifies the scope of changes determined by dam construction. Three dammed reservoirs located on Polish rivers were selected for analysis. They were different in size, hydrological regime and water management purposes. For each reservoir pair of water, gauges were selected. The input data were daily discharge series collected by the Polish Institute of Meteorology and Water Management. For each time series 20-year period before and after dam construction was established. Comparison of annual minimum flow ratios for these peri-ods as well as analysis of low flow dynamics and inertia allowed to identify range and direction of changes caused by investigated reservoirs.
\end{abstract}

Key words: low-flow regime, anthropogenic impact, dammed river discharge transformation

\section{Introduction}

Operations of water management concerning drought effect mitigation and implementation of strategies that optimize this process during reservoir retention steering has been developing for many years (Graf 1999). Results of this operational activity in short reaches directly up- and downstream of a dam were widely substantiated, especially in the matter of run-off stabilization, sediments and temperature (Schmidt and Wilcock 2008; Marren et al. 2014; Kirvel et al. 2015). However, in the successive stages of drought development (at the beginning - meteorological and finally - hydrological), downstream distribution of low flows is significantly modified by dam activity, which concerns reservoir zone as well as the needs of particular water consumers (Jiang et al. 2019). As a result of such water resources management, higher water shortage concentration might occur downstream and result in the consistent lengthening of low flows duration as well as deepening of streamflow deficit, estimated by minimum flows distribution.
The aim of this study was to assess the extent and range of low-flow regime changes in the scope of annual minimum flows caused by damming water in reservoirs.

\section{Data and Methods}

The study covered 3 dammed reservoirs located on Polish rivers (Fig. 1). First of them, placed in a mountainous basin, is the Czorsztyn Reservoir on the Dunajec river. It started in 1997 and its main purposes are flood control and hydropower (Table 1). In the year of completed, the reservoir proved its flood-control function effectiveness routing the flood wave of $0.1 \%$ probability of maximum discharge non-exceedance safely. The capacity of this deepest reservoir in relation to average annual river discharge seems to have a stabilizing effect on flow variability below the dam. Next, two dams were constructed on lowland rivers. The Sulejów Reservoir was completed in 1973 on the Pilica river. Its primary purpose was the water supply for a big and water needing, industrial agglomeration of Łódź 

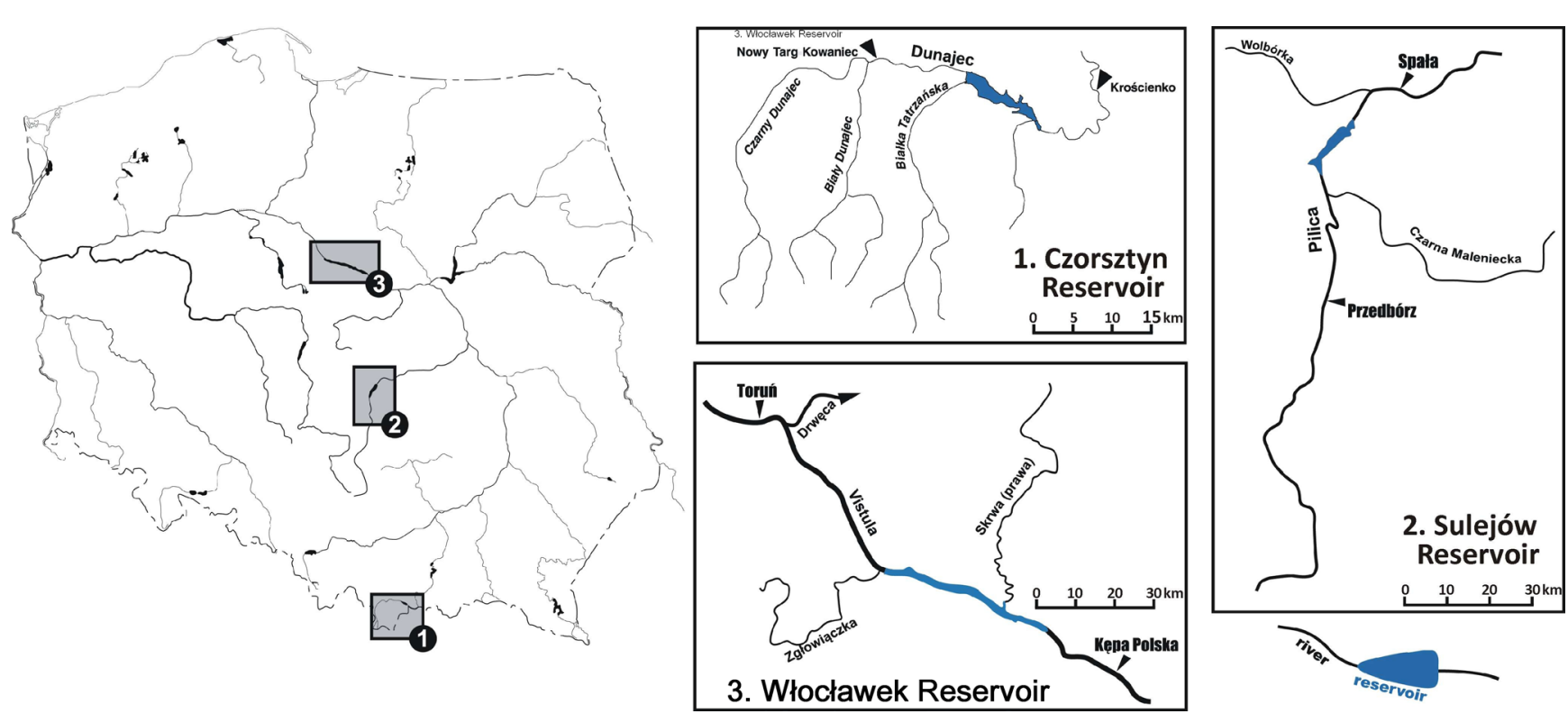

Fig. 1. Location of the investigated reservoirs and gauging cross-sections.

Table 1. Basic characteristics of the investigated reservoirs

\begin{tabular}{|c|c|c|c|c|c|c|}
\hline \multirow[t]{2}{*}{ Reservoir } & \multirow[t]{2}{*}{ River } & \multirow{2}{*}{$\begin{array}{c}\text { Year } \\
\text { completed }\end{array}$} & $\begin{array}{l}\text { Maximum } \\
\text { depth }\end{array}$ & $\begin{array}{l}\text { Maximum } \\
\text { surface area }\end{array}$ & Total capacity & \multirow[t]{2}{*}{ Main purposes } \\
\hline & & & [m] & {$\left[\mathrm{km}^{2}\right]$} & {$\left[\mathrm{hm}^{3}\right]$} & \\
\hline Czorsztyn & Dunajec & 1997 & 54.5 & 12.3 & 231.9 & \multirow{3}{*}{$\begin{array}{l}\text { flood control, hydropower, tourism } \\
\text { water supply (dismissed), hydro- } \\
\text { power, flood control, tourism } \\
\text { flood control, hydropower, naviga- } \\
\text { tion, tourism }\end{array}$} \\
\hline Sulejów & Pilica & 1973 & 11.3 & 23.8 & 84.3 & \\
\hline Włocławek & Vistula & 1970 & 12.7 & 75.0 & 453.6 & \\
\hline
\end{tabular}

According to Rzętała 2017 (modified)

City. Unfortunately, surface water intake was closed entirely at the beginning of the XXI century because of repetitive cyanobacterial algal blooms in the reservoir. The other dam purposes are connected with hydropower, tourism, recreation and limited flood control because of the small reservoir capacity. The Włocławek Reservoir on the Vistula river, which started in 1970, has the biggest surface but also is not too deep (Table. 1). Its main purposes are flood control, hydropower, and navigation. However, minimal reservoir capacity in relation to average annual discharge might produce some disturbances in water management operations and not guarantee a flow stabilization below the dam.

The basic input data were daily discharge series collected in gauging cross-sections located directly upstream and downstream of the investigated reservoirs (Fig. 1). The total observation period covered the years from 1951 to 2017. Discharge data was made available by the Polish Institute of Meteorology and Water Management.

The idea of identification of minimum flow changes caused by dam construction was based on an estimation of the change ratio between two periods. First of them - the calibration period, is characterized by natural or quasi-natural conditions of river discharge determination. In the second one, which is the evaluation period, the anthropogenic impact caused by dam construction is observed. It was assumed that 20-year stretch preceding dam construction is enough for reliable flow characteristics estimation in the calibration period. The same remark concerns the evaluation period after the dam was completed. The only exception was the Sulejów Reservoir, where mentioned periods reached 16 years only because of the lack of a long enough measurement series before dam construction.

For further investigation, an assumption was 
made that changes of flow observed in downstream gauging cross-sections are determined by flow changes in upstream cross-sections as well as by dam construction. The characteristic which allows assessing a quantitative aspect of changes between calibration and evaluation period in particular river cross-sections is a change ratio:

$$
C h R=\frac{F_{E}-F_{C}}{F_{C}} \cdot 100 \%
$$

where: $\mathrm{ChR}$ - change ratio [\%], $\mathrm{F}$ - flow index $\left[\mathrm{m}^{3} \mathrm{~s}^{-1}\right]$ in $\mathrm{C}$ - calibration, $\mathrm{E}$ - evaluation period (e.g., average annual minimum flow, etc.)

The sign of the estimated ratio indicates the direction of changes between periods, and the relative unit makes it fully comparable.

The impact of the dammed reservoir on river flow changes was estimated on the basis of simple difference between change ratios on downstream gauging cross-section and the upstream one:

$$
D I R=C h R_{D}-C h R_{U}
$$

where: DIR - dam impact ratio [\%], ChR change ratio [\%] in D - downstream cross-section, $\mathrm{U}$ - upstream cross-section

Assuming that difference reduces upstream discharge determinants, estimated values of dam impact ratio refers to direction and quantity of downstream minimum flow changes caused by new reservoir appearance.

On the basis of assumptions and equations presented above, the impact of dam construction on the dynamics of minimum downstream flows was also estimated. The Pearson's variation coefficient was applied (Kendall 1984):

$$
C v=\frac{S_{D}}{A_{V}}
$$

where: $C_{V}$ - variation coefficient of annual minimum flows, $S_{D}$ - standard deviation, $A_{V}$ - average value

Presented characteristic indicates relative dispersion of data, which is proportional to the index value. According to equations no. 1 and 2 , it was possible to assess how downstream dynamics of annual minimum flows were changed by dam construction.

Finally, the analysis of minimum flow inertia was based on the autocorrelation coefficient (Ken- dall 1984):

$$
R A_{m}=\frac{\sum_{n=1}^{N}\left[\left(x_{n}-x_{a v}\right) \cdot\left(x_{n-m}-x_{a v}\right)\right]}{\sum_{n=1}^{N}\left(x_{n}-x_{a v}\right)^{2}}
$$

where: $R A_{m}$ - autocorrelation coefficient with lag equal $m, n-$ number of observation, $m$ - lag, $\mathrm{x}_{\mathrm{av}}$ - average value, $\mathrm{N}$ - number of cases

Statistical significance of the estimated coefficients was verified on the level $\alpha=0.05$ on the basis of the Box-Ljung test (Liung and Box 1978). The analysis covered the first autocorrelation coefficient only (lag $=1$, one year in this case). Its value allowed assessing the minimum flow formation that is transmitted year by year. As a result, on the basis of equations 1 and 2 , the influence of dam construction on downstream low flows inertia was estimated.

\section{Results and discussion}

In the course of annual minimum flows of Dunajec river in gauging cross-section Nowy Targ, located upstream of the dam, a slight increase tendency between calibration and evaluation period is observed (Fig. 2A). The origin of this rise should be explained by natural factors, mostly by hydrometeorological conditions. Change ratios estimated for this cross-section are significant, especially for the lowest minimum flow. However, the distribution of minimum flows in both periods looks very similar, which might indicate a lack of new types of determinants in the evaluation period (Fig. 3A). In the gauging station situated downstream of the dam much stronger rise was noticed (Fig. 2B). Moreover, the lowest minimum flow in the evaluation period was higher than the highest minimum flow in the calibration period. Therefore, the observed course is characterized by abrupt changes more than continuous tendency. Estimated change ratios indicate the drastic impact of the dam on the lowest flows (more than 150\%), which transforms the base flow drainage process significantly in downstream rich (Fig. 3B). Average and the highest minimum flows changed similarly and crucial as well, which might be an effect of water management activity on the dam. The impact of new determinants in the evaluation period is also noticeable in the distribution of minimum flows (Fig. 3B) because of significant positive skewness with a concise range between first quartile and minimum value, which results from 

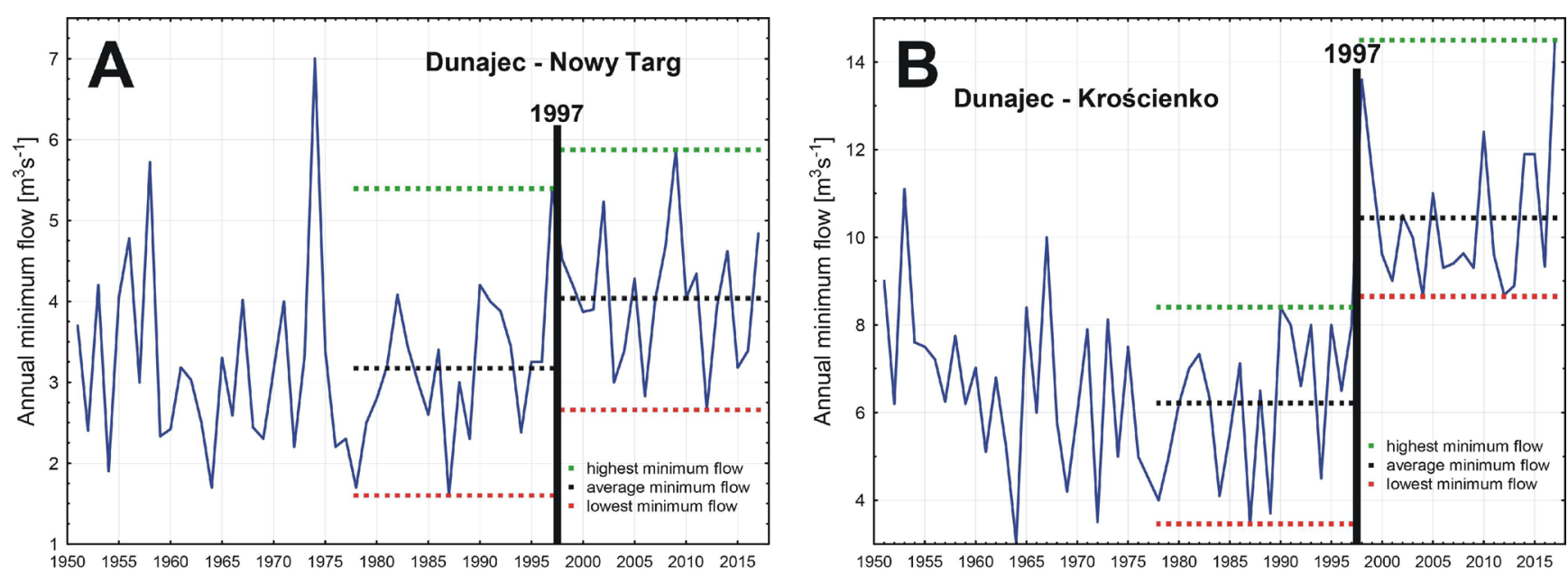

Fig. 2. The course of annual minimum flows in upstream (A) and downstream (B) gauging cross-sections of the Czorsztyn Reservoir. Explanations: year of dam completion divides calibration (before) and evaluation (after) period
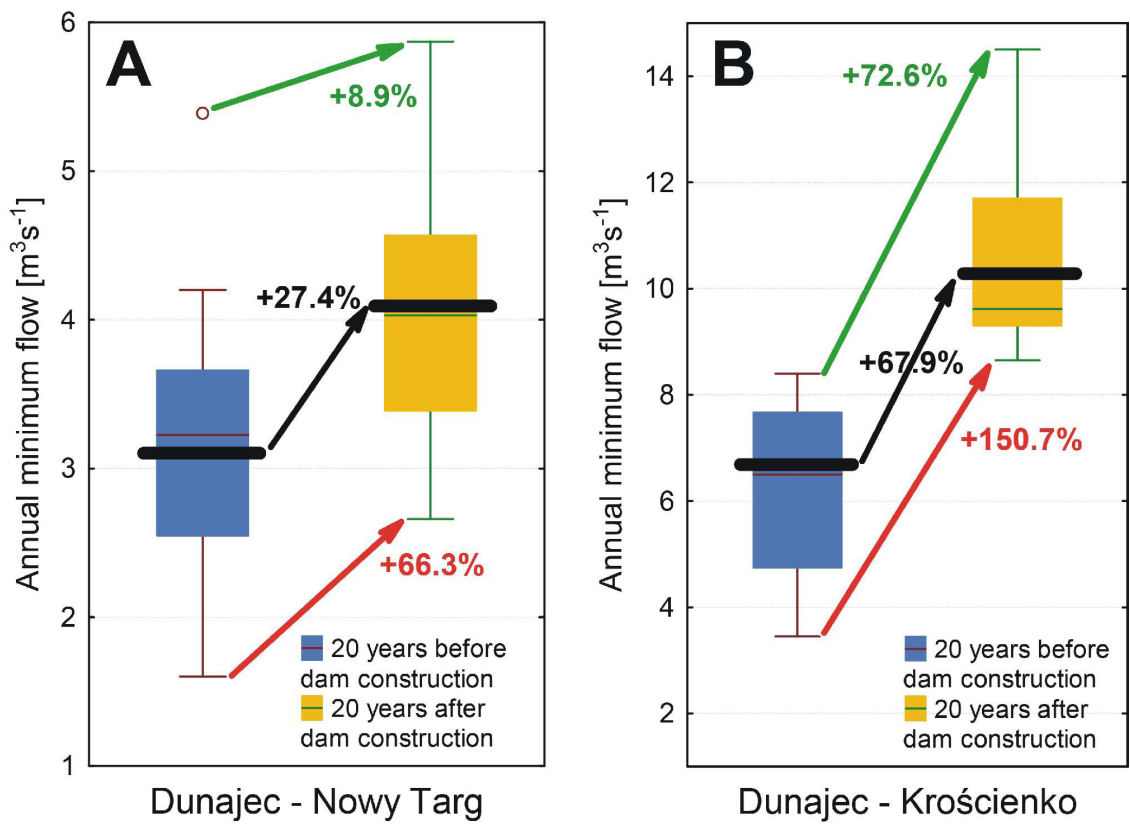

Fig. 3. Distribution of annual minimum flows and change ratios in upstream (A) and downstream (B) gauging cross-sections of the Czorsztyn Reservoir. Explanations: box marks range between 1st and 3rd quartile, inside median (thin line) and mean (thick line), whisker marks range limited by 1 quartile deviation, outliers are placed over 1 quartile deviation

guarantee flow production by the dam.

Estimating the direct impact of dam construction on minimum flow changes was made on the basis of assumptions from the previous chapter. Differences between change ratios indicate the high importance of the Czorsztyn Reservoir to downstream low flows transformation (Table 2). On average, the dam caused a $40 \%$ rise in minimum flows. It is a positive effect from a water management point of view because the reservoir fulfills the needs of its water consumers and improves downstream water resources availability. The $84 \%$ rise in the lowest minimum flow should limit severe hydrological droughts occurrence very effectively. Significant increases in the whole range of low flow variability support water management strategies in the scope of drought effects mitigation.

The Sulejów Reservoir located on the lowland Pilica river is characterized by much less capacity in relation to the previous one. In the course of annual minimum flows a very slight downward tendency was observed before and after dam construction in both gauging cross-sections (Fig. 4). However, high variability in the analyzed time series resulted in lo- 
Table 2. Change ratios of annual minimum flows between calibration and evaluation periods. Values are given as percentages

\begin{tabular}{cccccccccc}
\hline & \multicolumn{3}{c}{ Czorsztyn Reservoir } & \multicolumn{3}{c}{ Sulejów Reservoir } & \multicolumn{2}{c}{ Włocławek Reservoir } \\
\cline { 2 - 10 } $\begin{array}{c}\text { Annual } \\
\text { minimum flow }\end{array}$ & $\begin{array}{c}\text { Nowy } \\
\text { Targ }(\mathrm{u})\end{array}$ & $\begin{array}{c}\text { Krościenko } \\
(\mathrm{d})\end{array}$ & $\begin{array}{c}\text { Dam } \\
\text { impact } \\
(\mathrm{d}-\mathrm{u})\end{array}$ & $\begin{array}{c}\text { Przedbórz } \\
(\mathrm{u})\end{array}$ & $\begin{array}{c}\text { Spała } \\
(\mathrm{d})\end{array}$ & $\begin{array}{c}\text { Dam impact } \\
(\mathrm{d}-\mathrm{u})\end{array}$ & $\begin{array}{c}\text { Kępa } \\
\text { Polska } \\
(\mathrm{u})\end{array}$ & $\begin{array}{c}\text { Toruń } \\
(\mathrm{d})\end{array}$ & $\begin{array}{c}\text { Dam impact } \\
(\mathrm{d}-\mathrm{u})\end{array}$ \\
\hline Highest & +8.9 & +72.6 & +63.7 & +19.6 & -1.0 & -20.6 & +35.5 & +30.1 & -5.4 \\
Average & +27.4 & +67.9 & +40.5 & -6.9 & -7.0 & -0.1 & +34.4 & +18.5 & -15.9 \\
Lowest & +66.3 & +150.7 & +84.4 & -23.9 & +4.2 & +28.1 & +85.1 & +13.3 & -71.8 \\
\hline
\end{tabular}

Explanations: $\mathrm{u}$ - upstream gauging cross-section, $\mathrm{d}$ - downstream gauging cross-section, source: own elaboration
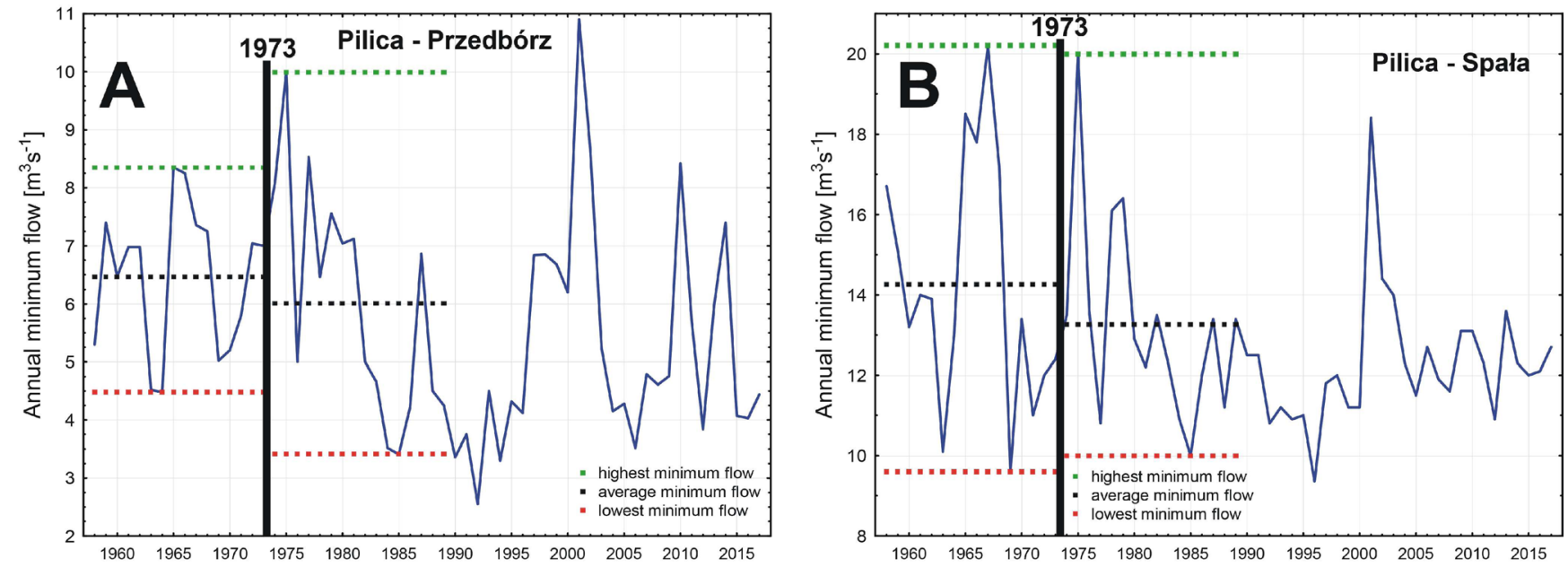

Fig. 4. The course of annual minimum flows in upstream (A) and downstream (B) gauging cross-sections of the Sulejów Reservoir. Explanations: see Fig. 2

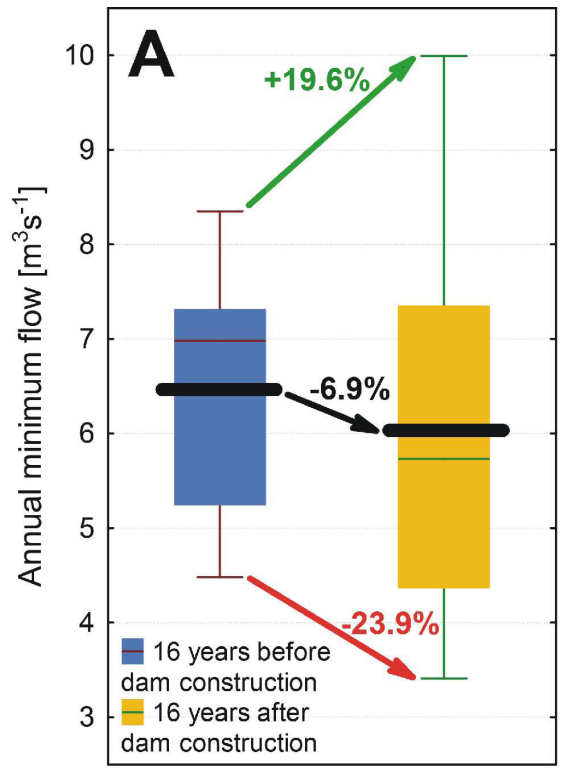

Pilica - Przedbórz

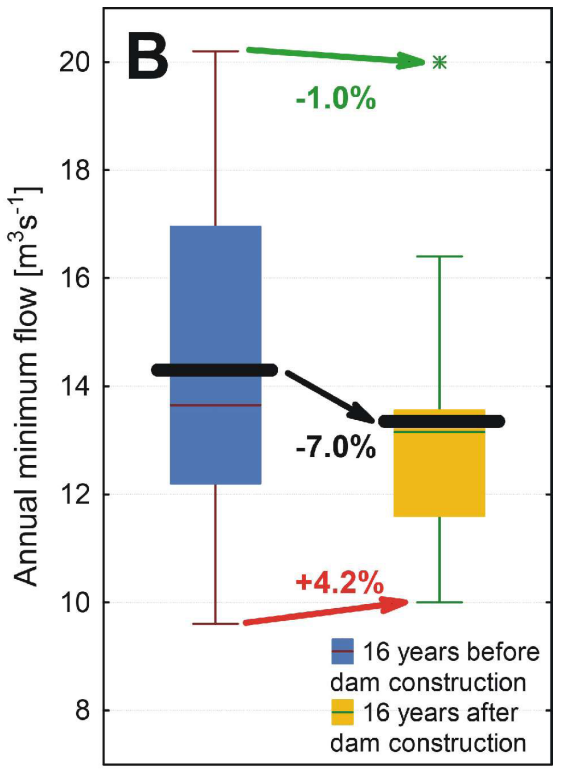

Pilica - Spała

Fig. 5. Distribution of annual minimum flows and change ratios in upstream (A) and downstream (B) gauging cross-sections of the Sulejów Reservoir. Explanations: see Fig. 3 
cal extremes reached every few years. Such a pattern determined various low flow directions (Fig. 5). It is interesting that an almost identical change ratio of average annual minimum flow in both gauging stations is accompanied by absolutely reverse tendencies in the highest and lowest low flows. These processes influence minimum flow distribution during evaluation periods, especially in downstream cross-section (Spała), where a high asymmetry coefficient resulting from strong negative skewness was noticed. Such a low flow structure indicates that in the river below the dam, serious low-flow periods and severe hydrological droughts might occur, particularly after series of dry years. When analyzing differences between change ratios, it should be noted that the Sulejów Reservoir completion did not affect annual minimum flows on average (Table. 2). However, the lowest minimum flows raised a bit, whereas the highest was reduced at the same level approximately. As a result, the Sulejów Reservoir produced guarantee flow, which mitigates streamflow deficits during seriously low-
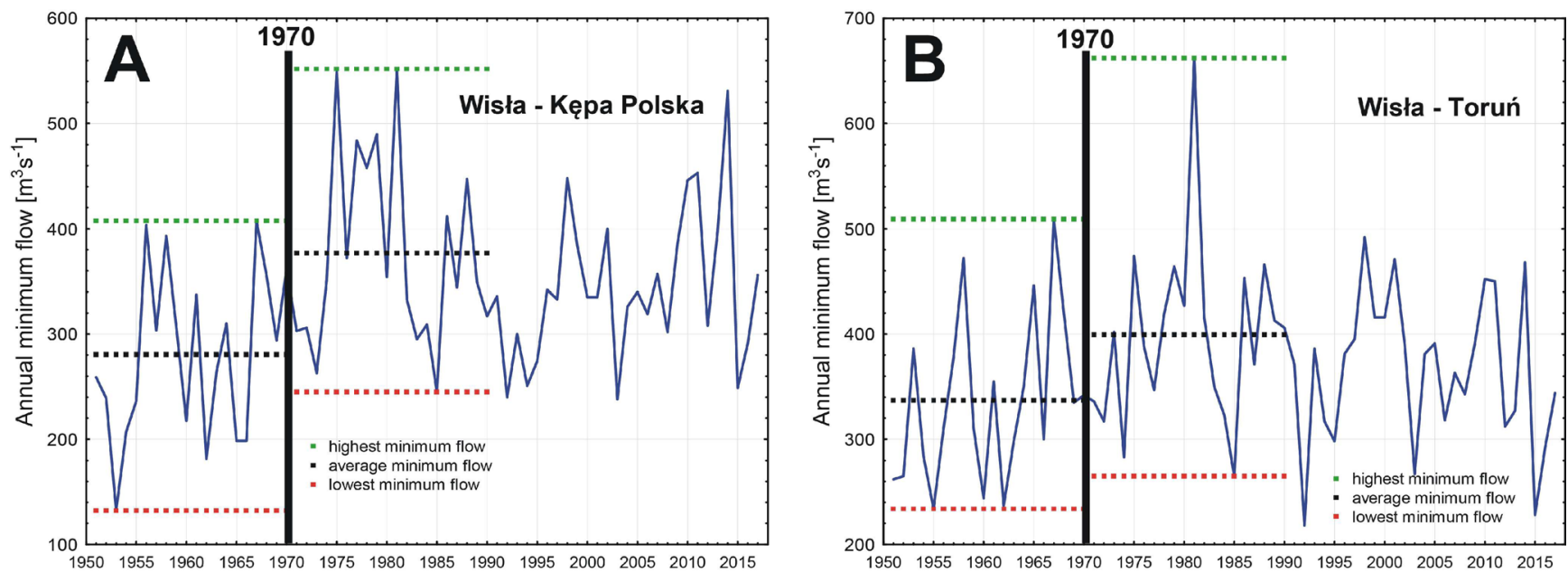

Fig. 6. The course of annual minimum flows in upstream (A) and downstream (B) gauging cross-sections of the Włocławek Reservoir. Explanations: see Fig. 2
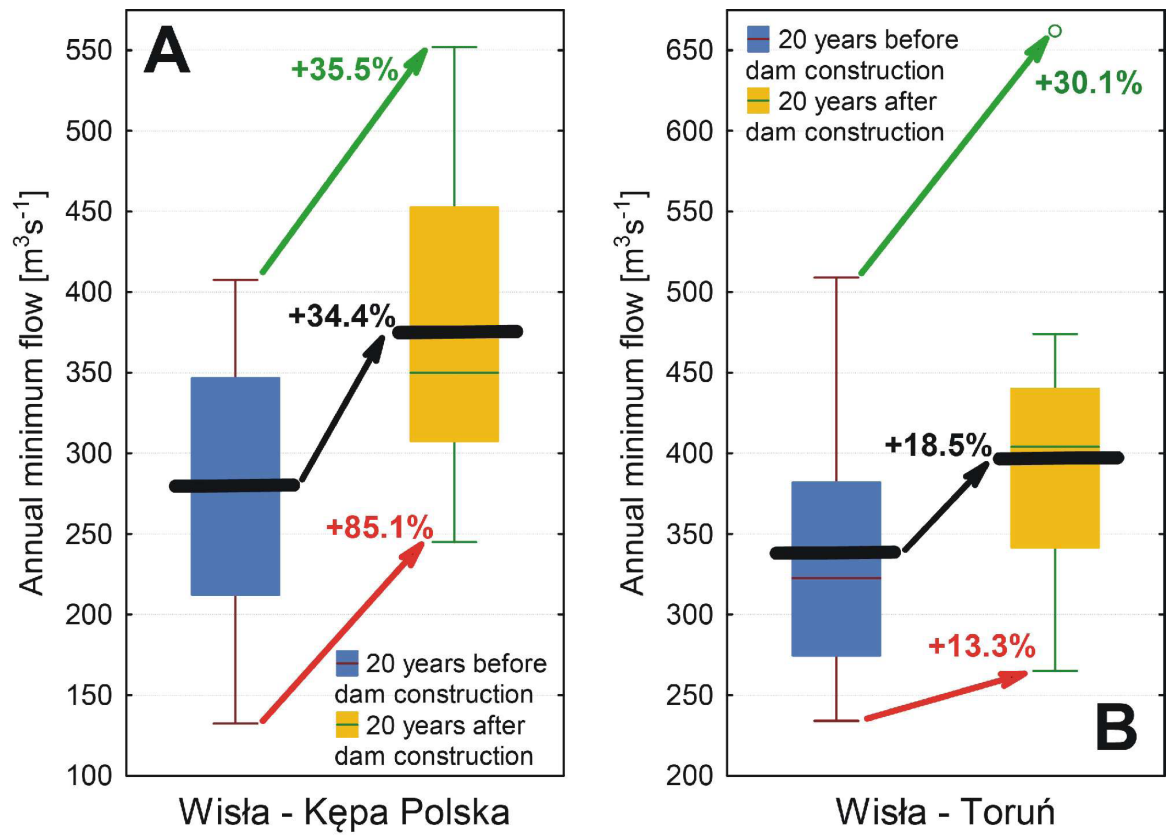

Fig. 7. Distribution of annual minimum flows and change ratios in upstream (A) and downstream (B) gauging cross-sections of the Włocławek Reservoir. Explanations: see Fig. 3. 

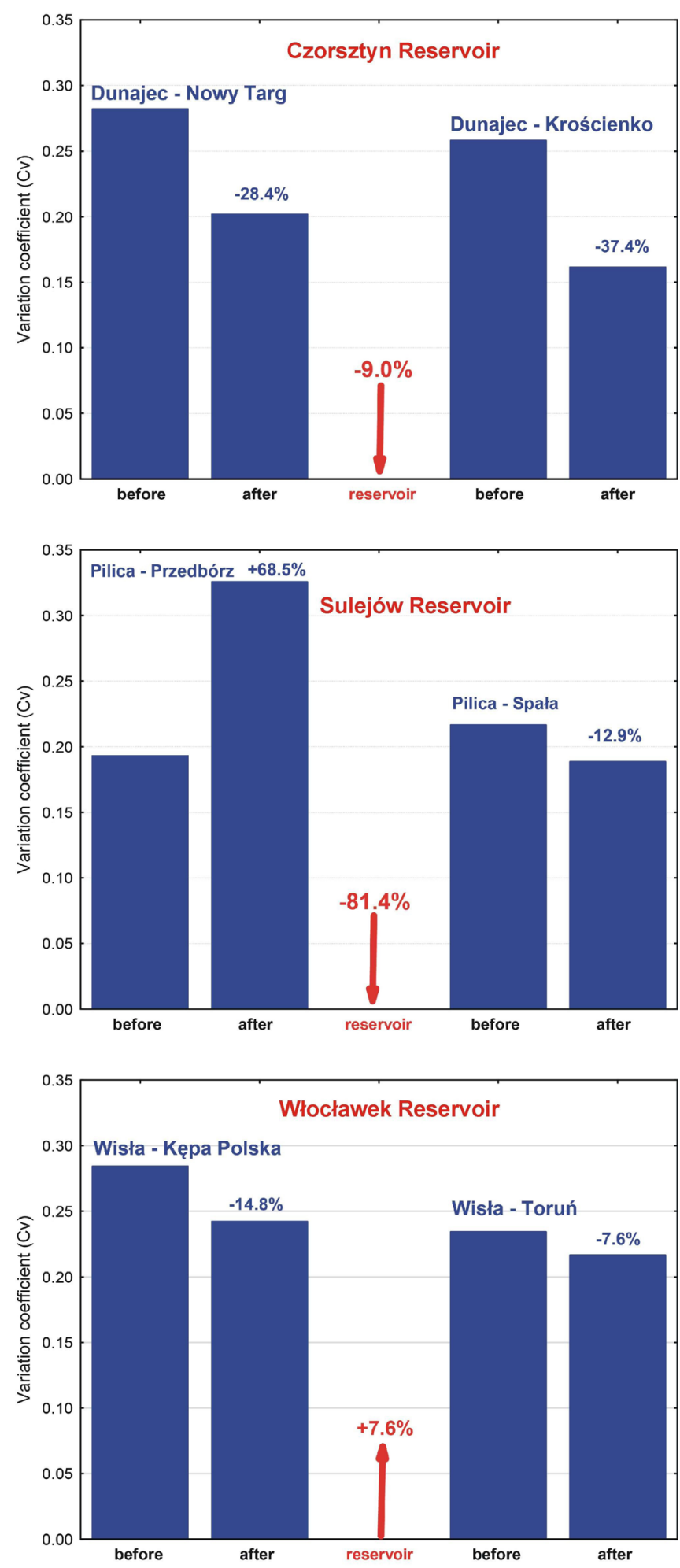

Fig. 8. Variation coefficients of annual minimum flows and change ratios in the investigated gauging cross-sections

flow periods, but typical water shortage seasons might cause temporary disturbances in downstream water resources availability. It is because of
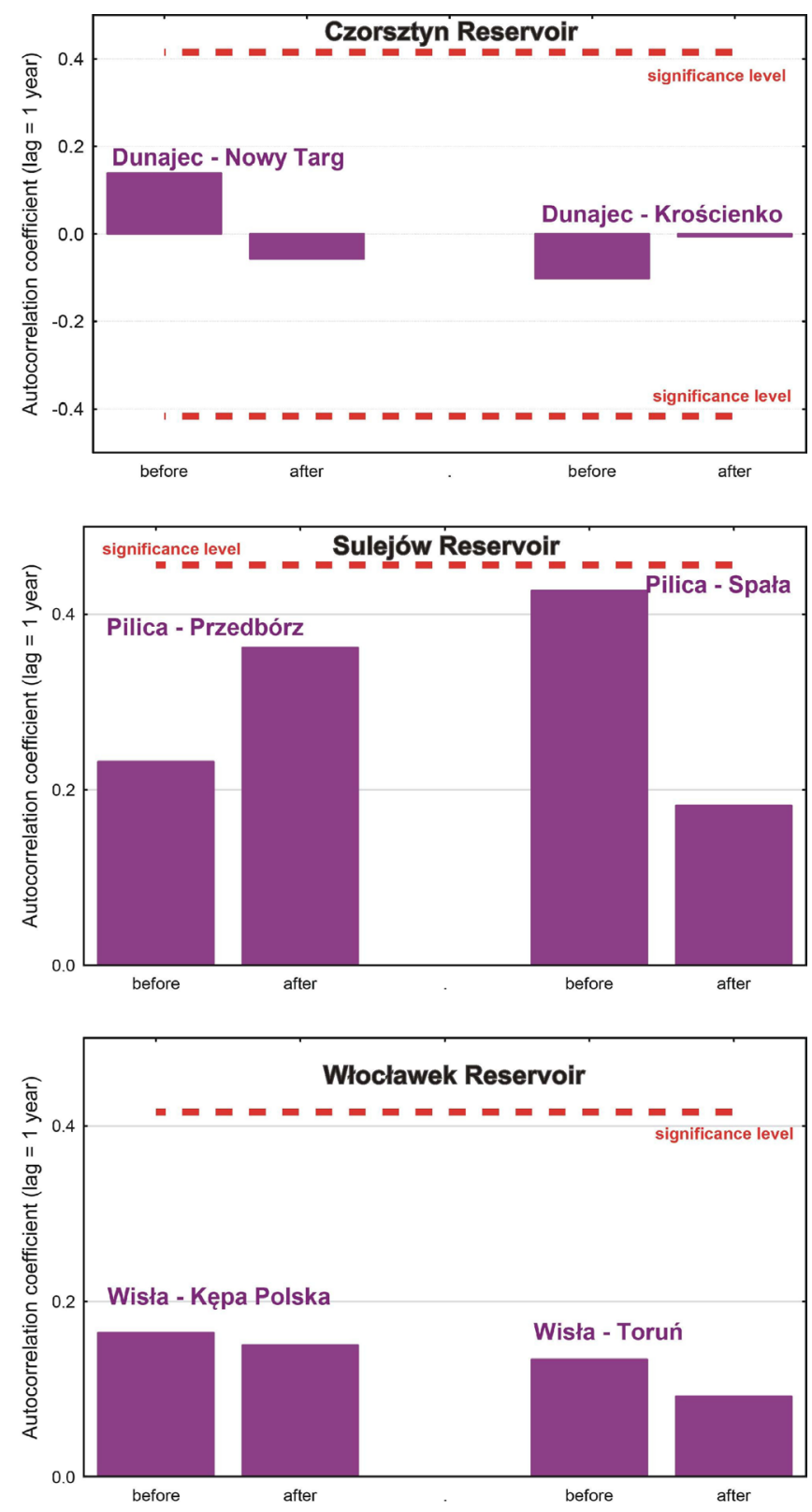

Fig. 9. Autocorrelation coefficients of annual minimum flows in the investigated gauging cross-sections

fulfilling needs of reservoir water consumers, water management dam operations as well as relatively small reservoir capacity in relation to annual average total flow, which results in small resistance to water resources changeability.

The Włocławek Reservoir on the Vistula river is the most capacious with the biggest surface area in the group of artificial water bodies (Table 1). However, as a lowland reservoir, it is shallow, and its capacity in relation to annual total discharge is not too big, similarly to the Sulejów Reservoir. 
When the dam was completed, time fell on the period of the significant upward tendency of annual minimum flows in upstream gauging cross-section (Fig. 6). In downstream water-gauge, this rise was not so dynamic. It is clearly proved in change ratios (Fig. 7). Distributions of annual minimum flows before and after dam construction changed not much but an increase of all ratios is weaker in the whole range of low flows changeability in downstream gauging cross-section (Toruń). Differences between ratios indicate that impact of the dam on low flows was very negative in the whole range of minimum flows variability (Table 2). As a result, reservoir existence caused many complications for downstream navigation and water resources availability under drought conditions. A significant decrease in the lowest minimum flows $(-78.1 \%)$ made the river below the dam very prone to severe hydrological drought development and serious perturbations for water management. The discussed reservoir was planned as a component of the Lower Vistula Cascade but still works alone, causing some malfunctions to determine adverse changes of downstream low-flow regime.

The multiannual dynamic of minimum flows before and after dam construction was analysed on the basis of Pearson's variation coefficient. After the Czorsztyn Reservoir had started, downstream minimum flow variability decreased about $37 \%$, and $9 \%$ of this stabilization should be attributed to dam operation only (Fig. 8). It is a significant value and in connection with $40 \%$ rise of minimum, flows give useful tools for water management under drought conditions. In gauging cross-section located below the Sulejów Reservoir, multiannual low flows stabilization reached only $13 \%$, whereas in upstream water gauge very high increase of variability was noticed (69\%). As a result, estimating the difference between change ratios, the Sulejów Reservoir is identified to produce almost $82 \%$ of low flow stabilization in the lower stage of the river. This is a very positive feature useful for hydrological drought effects mitigation. However, it should be remembered that there was not increase in average minimum flows in this case. Therefore such huge stabilization caused by water management activity on the dam cannot provide resources for water shortage seasons. In the consequence of the Włocławek Reservoir activity, an increase of minimum flows variability was noticed, which made the downstream low-flow regime more dynamic (Fig. 8). If we add to this significant recession in the whole range of low flows generated by the dam, serious disturbances in water management under drought conditions in the river below the reservoir should be expected.

Anthropogenic impact on river discharge and water resources, especially low flows, is characterized by an elevated level of inertia (Smakhtin 2001; Tomaszewski 2016). River flow values in consecutive time steps (days, months, years) are correlated with previous values because of the continuity of water management activity. A good measure of inertia in time series is the autocorrelation coefficient (Kendall 1984). From a hydrological point of view, its value valorizes the quantity of information about discharge, transmitted step by step (Tomaszewski 2012). In the long time steps, autocorrelation is decreasing in natural conditions, and if not, it might indicate a serious influence of artificial factors. Analysis of autocorrelation coefficients indicates no statistically significant results (Fig. 9). It means that natural determinants were much more important in this matter than artificial. Moreover, there was no clear tendency in coefficients pattern, which entitles to making a statement that this process has a stochastic nature in the long-term scale.

\section{Conclusions}

The presented analyses proved that the river low-flow regime follows multidirectional changes after dam construction. Taking an assumption about the difference between low flow change ratios allowed to estimate the direct influence of dam construction on downstream minimum flow changes. The main determinant in this matter seems to be a relation between reservoir capacity and annual flow ratio as well as purposes of reservoir water management. As a result, two main hydrological kinds of transformation was discovered:

relatively capacious mountainous reservoirs (the Czorsztyn Reservoir) where significant increase and stabilization in minimum flows was observed. It might give adequate support for water management strategies of drought effects mitigation,

shallow lowland reservoirs (the Sulejów and Włocławek reservoirs) characterized by the lack or decrease tendency in average annual minimum flows, unstable changes in low-flows vari- 
ability, slight or serious increase of streamflow deficits after dam construction. Such kind of changes makes the river below the dam very prone to severe hydrological drought development and serious perturbations for water management.

Absolutely lack of statistically significant inertia in annual minimum flow series in calibration and evaluation periods indicates that natural determinants were much more important in this matter than artificial.

\section{References}

Graf W.L., 1999, Dam nation: A geographic census of American dams and their large-scale hydrologic impacts, Water Resour. Res. 35(4): 1305-1311.

Jiang C., Zhang Q., Luo M., 2019, Assessing the effects of the Three Gorges Dam and upstream inflow change on the downstream flow regime during different operation periods of the dam, Hydrol. Process. 33: 2885-2897.

Kendall M.G., 1984, Time Series, Oxford University Press, New York, 296 pp.

Kirvel I., Kukshinov M., Kirvel P., 2015, The transforma- tion of rivers' temperature regime downstream of reservoirs, Limnol. Rev. 15(4): 165-170.

Ljung G.M., Box G.A.P., 1978, On a measure of a lack of fit in time series models, Biometrica 65(2): 297-303.

Marren P.M., Grove J.R., Webb J.A., Stewardson M.J., 2014, The potential for dams to impact lowland meandering river floodplain geomorphology, Sci. World J. 2014: \#309673.

Rzętała M., 2017, Sztuczne zbiorniki wodne i ich funkcje (Artificial water reservoirs and their functions), [in:] Jokiel P., Marszelewski W., Pociask-Karteczka J. (eds), Hydrologia Polski (Hydrology of Poland), PWN, Warszawa: 240-246 (in Polish).

Smakhtin V.U., 2001, Low flow hydrology: a review, J. Hydrol. 240(3-4): 147-186.

Schmidt J.C., Wilcock P.R., 2008, Metrics for assessing the downstream effects of dams, Water Resour. Res 44(4): \# W04404.

Tomaszewski E., 2012, Wieloletnia i sezonowa dynamika niżówek w rzekach środkowej Polski (Multiannual and seasonal dynamics of low flows in rivers of central Poland), Wydaw. UŁ, Łódź, 265 pp (in Polish, English summary).

Tomaszewski E., 2016, Impact of Lake Gopło on lowflow regime of the upper Noteć river, Limnol. Rev. 16(2): 95-103. 